\title{
$E_{4} 5.2$
}
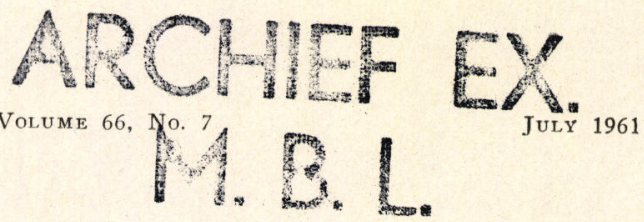

\section{Origin of Radioactive Fallout in the Northern Hemisphere after the Spring Maximum in 1959}

\author{
J. F. Bleichrodt, Joh. Blok, and E. R. van AbKoude \\ Medical Biological Laboratory of the National Defence Research Organization TNO \\ Rijswijk, Z. H., The Netherlands
}

\begin{abstract}
Evidence is presented that an insignificant fraction of debris from the Soviet nuclear test explosions in October 1958 was present in the lower stratosphere at the end of 1959 and that fallout during 1960 mainly originated from injections into the tropical stratosphere during 1958 .
\end{abstract}

Th ntroduction. Recently several attempts have made to estimate the contribution of $\mathrm{Sr}^{90}$ originating from the Hardtack nuclear test explosions at Bikini $\left(11^{\circ} \mathrm{N}, 165^{\circ} \mathrm{E}\right)$ and Eniwetok $\left(11^{\circ} \mathrm{N}, 162^{\circ} \mathrm{E}\right)$ in May, June, and July, 1958 , and from the Soviet detonations north of the arctic circle in October 1958 to the total $\mathrm{Sr}^{90}$ fallout since the autumn of 1958 [Lockhart, Patterson, Saunders, and Black, 1960a, b; Martell and Drevinsky, 1960; Walton, 1960]. These estimates were possible because the unique tracer tungsten 185 (half-life 75.8 days [Strominger, Hollander, and Seaborg, 1958]) was introduced into the stratosphere by some of the Hardtack explosions. An estimated value for the $\mathrm{W}^{185} / \mathrm{Sr}^{90}$ radioactivity ratio on an average explosion date was used to calculate the contribution of Hardtack $\mathrm{Sr}^{90}$ from $\mathrm{W}^{185}$ data. The percentage of $\mathrm{Sr}^{90}$ from the Soviet October tests was evaluated by means of the $\mathrm{Sr}^{89} / \mathrm{Sr}^{90}$ ratio after subtraction of the amount of $\mathrm{Sr}^{89}$ associated with Hardtack debris om the total $\mathrm{Sr}^{89}$ measured.

In studying atmospheric transport of debris from nuclear explosions in 1958, it is of importance to know the contribution of $\mathrm{Sr}^{90}$ of both tropical and polar origin to total $\mathbf{S r}^{90}$ fallout. However the reliability of the results of calculations as mentioned above is strongly dependent on the estimated $\mathrm{W}^{185} / \mathrm{Sr}^{90}$ ratio in Hardtack material (the $\mathrm{Sr}^{89} / \mathrm{Sr}^{90}$ ratio at the moment of explosion is fairly well known). Moreover, knowledge of the percentage of Hardtack $\mathrm{Sr}^{90}$ in fallout does not give information on the percentage of $\mathrm{Sr}^{90}$ originating from the tropical stratosphere. At least the contribution of the United Kingdom tests in April and September in the Christmas Island area $\left(2^{\circ} \mathrm{N}, 157^{\circ} \mathrm{W}\right)$ should be taken into account.
Recent data suggest that the contribution of $\mathrm{Sr}^{90}$ of tropical origin to fallout in 1959 was substantially higher than the amount estimated from the $W^{185}$ fallout and that since the end of 1959 fallout originated mainly from injections into the tropical stratosphere. This means that essentially no debris from the Soviet October 1958 tests was left in the lower stratosphere at the end of 1959.

Experimental procedures. $\mathrm{Sr}^{90}$ (half-life 28 years) and $\mathrm{Ce}^{144}$ (half-life 285 days) were isolated from monthly rain-water samples collected by exposing pots with a diameter of about $45 \mathrm{~cm}$ and a height of about $40 \mathrm{~cm}$. Inactive carriers were added to the pots before exposure. The amount of rainfall during the collection period was measured with a rain gage which was emptied three or more times a week. The nuclides were separated according to the method of Osmond, Owers, Healy, and Mead [1959]. Sr ${ }^{90}$ was purified radiochemically by the procedure of the same authors, $\mathrm{Ce}^{144}$ by that of Glendenin, Flynn, Buchanan, and Steinberg [1955]. Insoluble residues were analyzed separately for $\mathrm{Ce}^{144}$, because it was found that sometimes about 25 per cent of $\mathrm{Ce}^{144}$ remained in the residue after extraction with nitric acid.

$\mathrm{W}^{185}$ was isolated from monthly rain-water samples similarly collected as described above, using the procedure of Welford, Collins, Sutton, and Morse [1959]. The $\mathrm{W}^{185} / \mathrm{Sr}^{90}$ ratios for October, November, and December, 1960, however, have been obtained by analyzing rain samples (80 to 100 liters) collected with a stainless steel tray of $1 \mathrm{~m}^{2}$.

The radioactivity of the purified nuclides was measured with a Geiger-Müller counting setup, 
calibrated by means of standardized solutions of various nuclides with different $\beta$ energies.

In the beginning of $1960, \mathrm{~W}^{185}$ activities had decreased to such low values that reliable activity measurements could not be carried out. Since that time the $\mathrm{X}$ radiation (about $57 \mathrm{kev}$ ) of the isotope $\mathrm{W}^{181}$ (half-life 126 days [Kreger and Lynn, 1960]), which was also produced during the Hardtack series, has been measured. By determining both the $\mathrm{W}^{181}$ and $\mathrm{W}^{185}$ activity (corrected for radioactive decay to a common date) in a number of fallout samples it was possible to determine the factor by which the $\mathrm{W}^{181}$ activity of a sample must be multiplied to obtain the $W^{185}$ activity.

All measurements have been carried out in duplicate except $\mathrm{W}^{186} / \mathrm{Sr}^{90}$ determinations in October, November, and December, 1960. Sr ${ }^{90}$ duplicates seldom differed more than 10 per cent; $\mathrm{Ce}^{144}$ duplicates showed larger differences. The standard error of the $\mathrm{Ce}^{144} / \mathrm{Sr}^{90}$ ratios has been estimated by statistical analysis of the $\mathrm{Ce}^{144} / \mathrm{Sr}^{90}$ duplicate values. The standard error of the $\mathrm{W}^{186} / \mathrm{Sr}^{90}$ ratios is estimated at about 12 per cent.

Results and discussion. In Figure $1 \mathrm{Ce}^{144} / \mathrm{Sr}^{90}$ ratios at Rijswijk, Z. H. $\left(52^{\circ} 3^{\prime} \mathrm{N}, 4^{\circ} 20^{\prime} \mathrm{E}\right)$, have been plotted for the period 1958 through 1960, corrected for radioactive decay to the arbitrarily chosen date November 1, 1958. Data for Milford Haven $\left(51^{\circ} 43^{\prime} \mathrm{N}, 5^{\circ} 2^{\prime} \mathrm{W}\right)$ [Crooks, Osmond, Owers, and Fisher, 1959; Crooks, Osmond, Fisher, Owers,

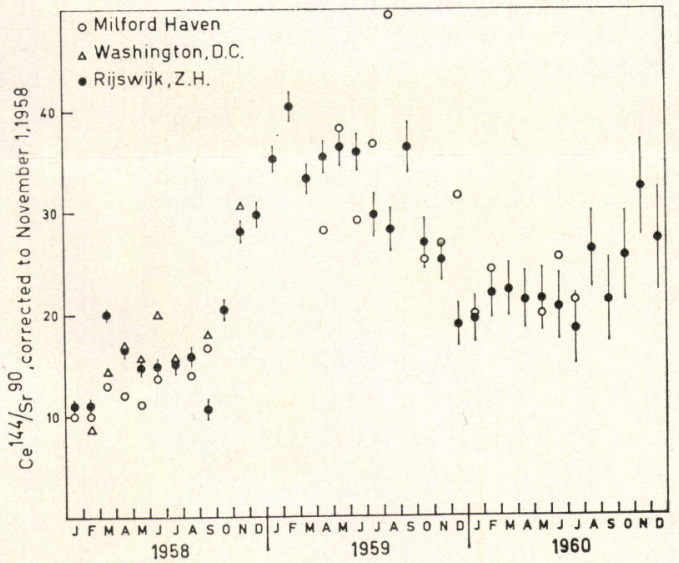

Fig. 1. $\mathrm{Ce}^{144} / \mathrm{Sr}^{90}$ ratios in rain water at Rijswijk, Z. H., and Milford Haven, England, and in air at Washington, D. C., corrected for radioactive decay to November 1,1958 . The vertical lines represent one standard error. and Evett, 1960] and for Washington, D. C. $\left(38^{\circ} 50^{\prime} \mathrm{N}, 77^{\circ} 0^{\prime} \mathrm{W}\right)$ [Lockhart, Baus, Patterson, and Saunders, 1959], have been included for comparison.

After August 1958 the $\mathrm{Ce}^{144} / \mathrm{Sr}^{90}$ ratio started to increase with the arrival of fresh debris from the Hardtack and Soviet October detonations. A maximum was reached during the spring of 1959 when most of the long-lived fission products originated from the Soviet series [Bleichrodt, Blok, and Dekker, 1961]. Then $\mathrm{Ce}^{144} / \mathrm{Sr}^{90} \mathrm{de}-$ creased due to a diminishing contribution of Soviet debris. Since December 1959 the $\mathrm{Ce}^{144} / \mathrm{Sr}^{90}$ ratio has remained approximately constant, suggesting either that the lower stratosphere the northern hemisphere was well mixed or tha fallout material was fed into the troposphere from two or more stratospheric sources at approximately proportional rates.

In Table 1 the $\mathrm{W}^{185} / \mathrm{Sr}^{90}$ ratios in rain water at Rijswijk are given, corrected for radioactive decay to June 15,1958 . No large fluctuations are observed. This supports the conclusion drawn from the $\mathrm{Ce}^{144} / \mathrm{Sr}^{90}$ ratios.

TABLE 1. W ${ }^{185}$ Fallout at Rijswijk, Z. H., Corrected for Decay to June 15, 1958

\begin{tabular}{lrcc}
\hline $\begin{array}{l}\text { Sampling } \\
\text { Period }\end{array}$ & $\begin{array}{c}\mathrm{W}^{185}, \\
\mathrm{pc} / 1^{*}\end{array}$ & $\begin{array}{c}\text { Rainfall, } \\
\mathrm{mm}\end{array}$ & $\mathrm{W}^{185} / \mathrm{Sr}^{90}$ \\
\hline \multicolumn{1}{c}{1959} & & & \\
June & 1000 & 27 & 72 \\
July & 380 & 63 & 54 \\
August & 280 & 44 & 60 \\
September & 1390 & 3.1 & $187 \dagger$ \\
October & 98 & 91 & 74 \\
November & 113 & 50 & 81 \\
December & 81 & 74 & 66 \\
$\quad 1960$ & & & \\
January & 70 & 89 & 42 \\
February & 187 & 33 & 77 \\
March & 420 & 15.5 & 90 \\
April & 143 & 36 & 42 \\
May & 129 & 49 & 40 \\
June & 187 & 36 & 54 \\
July & 98 & 58 & 48 \\
October & & & 49 \\
November & & & 58 \\
December & & & 30 \\
& & & \\
\hline
\end{tabular}

* $1 \mathrm{pc} / 1=10^{-12}$ curie per liter.

† Rainfall was extremely light during this month, resulting in low radioactivity. The $\mathrm{Cs}^{137} / \mathrm{Sr}^{90}$ ratio was 5.0. The average value for 1959 , the September value not included, was 2.1. Therefore it seems probable that the $\mathrm{Sr}^{90}$ result was too low by a factor of about 2.5. 


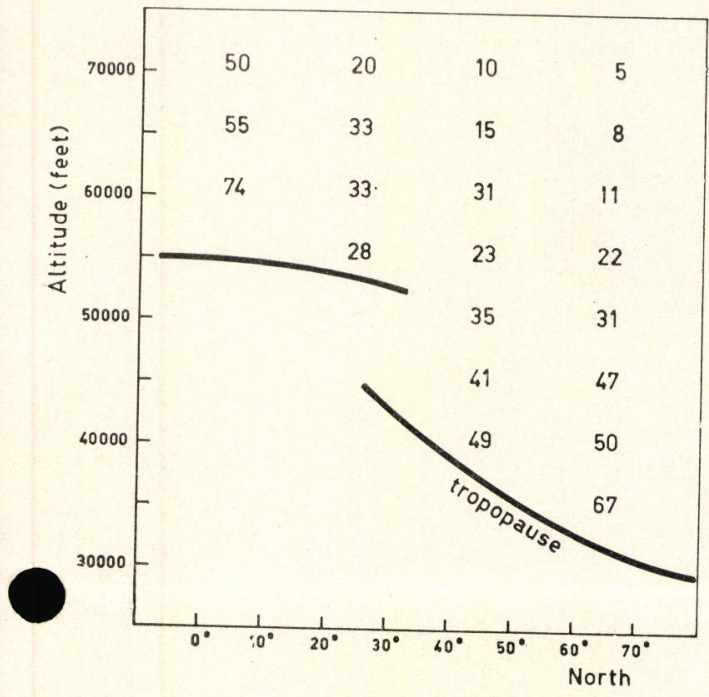

Fig. 2. $\mathrm{W}^{185} / \mathrm{Sr}^{90}$ ratios in the lower stratosphere of the northern hemisphere during NovemberDecember 1959, corrected for radioactive decay to June 15,1958 . $\mathrm{W}^{185}$ and $\mathrm{Sr}^{90}$ data have been derived from Figure 1 of Feely and Spar [1960].

The possibility that during 1960 radioactive debris was fed into the troposphere from two or more sources of different composition with approximately proportional rates must be excluded on the basis of stratospheric $\mathrm{W}^{185}$ and $\mathrm{Sr}^{90}$ data. Feely and Spar [1960] recently published vertical profiles of $\mathrm{W}^{185}$ and $\mathrm{Sr}^{90}$ in the lower stratosphere for the period November-December 1959. Figure 2 shows $\mathrm{W}^{185} / \mathrm{Sr}^{90}$ ratios in the lower stratosphere obtained from Figure 1 of Feely and Spar. The data have been corrected for dioactive decay (half-life $W^{185}=75.8$ days) vo June 15,1958 , in order to facilitate comparison with the data of Table 1.

It is apparent from Figure 2 that at the end of 1959 in the lower stratosphere of the northern hemisphere $\mathrm{W}^{185}$ and $\mathrm{Sr}^{90}$ were well mixed in layers which roughly parallel the tropopause. In the lower layers the $\mathrm{W}^{186} / \mathrm{Sr}^{90}$ ratio is comparable with the ratio found in rain water during 1960. It may be concluded that fallout during 1960 consisted mainly of material residing in the lower $15,000 \mathrm{ft}$ of the stratosphere during November-December 1959. This is in agreement with the view that vertical mixing is slow in the stratosphere.

According to Feely and Spar [1960] from September 1958 up to April 1960 at least, the maximum $W^{185}$ concentration in the stratosphere was found over the equator at about $70,000 \mathrm{ft}$. Changes in the distribution of $\mathrm{W}^{185}$ in the stratosphere during this period point to a transport of this nuclide by large-scale mixing in a layer sloping downward from the equatorial maximum towards the north pole. Above this layer the $\mathrm{W}^{185}$ concentration decreased with increasing altitude. As far as data were available for the southern hemisphere the situation was found to be roughly symmetrical about the equator with somewhat lower concentrations in the southern hemisphere.

The permanent $\mathrm{W}^{185}$ maximum in the equatorial stratosphere together with approximately constant $\mathrm{W}^{185} / \mathrm{Sr}^{90}$ ratios in the layers of latitudinal mixing at the end of 1959 (Fig. 2) suggest that Hardtack $\mathrm{Sr}^{90}$ in the equatorial stratosphere has not been diluted appreciably by $\mathrm{Sr}^{90}$ from the Soviet detonations in October 1958. In case of dilution the $\mathrm{W}^{185} / \mathrm{Sr}^{90}$ ratio would be expected to decrease with increasing latitude in the layers of mixing. Absence of dilution can also explain the stratospheric $\mathrm{Sr}^{89} / \mathrm{Sr}^{90}$ ratio in the northern hemisphere. From November 1958 to November 1959 this ratio was found to be fairly uniform in the lower stratosphere between $5^{\circ}$ and $65^{\circ} \mathrm{N}$ and to decrease in accordance with the half-life of $\mathrm{Sr}^{89}$ [Stebbins, 1960]. It is highly improbable that such a uniform distribution of $\mathrm{Sr}^{89} / \mathrm{Sr}^{90}$ at the end of 1958 resulted from mixing of equatorial debris and dust from the arctic tests in October 1958.

From these arguments it follows also that by the end of 1959 no dust from the Soviet October 1958 detonations was present in the lower stratosphere between $5^{\circ}$ and $70^{\circ} \mathrm{N}$.

The presence of Soviet October 1958 debris in the lower stratosphere north of $70^{\circ}$ cannot be excluded from the data in Figure 2. It is to be expected that $\mathrm{Sr}^{90}$ from the Soviet tests still present in this part of the stratosphere at the end of 1959 would enter the troposphere during the spring of 1960 [Bleichrodt, Blok, and Dekker, 1961], causing a decrease in $\mathrm{W}^{185} / \mathrm{Sr}^{90}$ and an increase in $\mathrm{Ce}^{144} / \mathrm{Sr}^{90}$ in rain water. However, both ratios remained approximately constant during the spring of 1960 .

Martell and Drevinsky [1960] assumed that the $\mathrm{W}^{185} / \mathrm{Sr}^{90}$ ratio of stratospheric Hardtack debris was 380 on June 15, 1958; Lockhart and others [1960a] assumed a ratio of 500 for July 15, 1958. If these values reflect the true order of magni- 
tude, this implies that $\mathrm{Sr}^{90}$ present in the equatorial stratosphere before the Hardtack tests commenced and $\mathrm{Sr}^{90}$ from the United Kingdom explosions diluted Hardtack $\mathrm{Sr}^{90}$ by a factor of 6 to 10 (Fig. 2). This is supported by measurements of Martell and Drevinsky at Pôrto Alegre $\left(30^{\circ} 5^{\prime} \mathrm{S}, 51^{\circ} 3^{\prime} \mathrm{W}\right)$ during the period August 1958 to March 1959 . The average $\mathrm{Sr}^{89} / \mathrm{Sr}^{90}$ ratio corrected for decay to June 15, 1958, was found to be $208 \pm 48$, indicating fallout of recent explosions. The $\mathrm{W}^{185} / \mathrm{Sr}^{90}$ ratio, however, was $97 \pm 17$.

In a recent calculation of the percentage of $\mathrm{Sr}^{90}$ originating from the Soviet October 1958 explosions in fallout during 1959 [Bleichrodt and others, 1961] all $\mathrm{Sr}^{89}$ in fallout since January 1959 was ascribed to the Soviet tests, because the contribution of Hardtack $\mathrm{Sr}^{89}$ estimated for a $\mathrm{W}^{185} / \mathrm{Sr}^{90}$ ratio of 500 [Lockhart and others, 1960a] was negligible. However, the arguments presented above suggest that, to estimate the amount of $\mathrm{Sr}^{89}$ of tropical origin, a much lower $\mathrm{W}^{185} / \mathrm{Sr}^{90}$ ratio should be used. Nevertheless it can be shown that, during the spring maximum in 1959 , $\mathrm{Sr}^{90}$ originated predominantly from the detonations in October 1958.

An estimation of the contribution of equatorial $\mathrm{Sr}^{90}$ in 1959 can be made in a more accurate way on the basis of stratospheric $\mathrm{Sr}^{89} / \mathrm{Sr}^{90}$ ratios [Stebbins, 1960]. As was shown above, in 1959 $\mathrm{Sr}^{89}$ in the stratosphere between $5^{\circ}$ and $65^{\circ} \mathrm{N}$ was of tropical origin. Extrapolation of $\mathrm{Sr}^{89} / \mathrm{Sr}^{90}$ to October 15,1958 , results in a $\mathrm{Sr}^{89} / \mathrm{Sr}^{90}$ ratio of about 60 . If the $\mathrm{Sr}^{89} / \mathrm{Sr}^{90}$ ratio for October 1958 debris is assumed to be 180 on October 15 , 1958 , the fraction $x$ of debris of tropical origin in fallout at any time during 1959 can then be calculated from

$$
60 x+180(1-x)=A
$$

where $A$ represents the measured $\mathrm{Sr}^{89} / \mathrm{Sr}^{90}$ ratio corrected to October 15, 1958.

In Table 2 results are given for Rijswijk, Abingdon, and Milford Haven, calculated from data of Bleichrodt and others [1961] and Crooks and others [1960]. It is seen that during the spring maximum in 1959 some 15 to 30 per cent of $\mathrm{Sr}^{90}$ fallout originated from equatorial explosions, so the more accurate calculation modifies the values given previously to a slight extent only. In the autumn of 1959 , however, the contribution of
TABLE 2. Contribution of $\mathrm{Sr}^{90}$ from Explosions in Tropical Regions to $\mathrm{Sr}^{90}$ Fallout during 1959

\begin{tabular}{lccc}
\hline & \multicolumn{2}{c}{ Tropical Sr $^{90}$ (percentage of total) } \\
\cline { 2 - 4 } $\begin{array}{l}\text { Sampling } \\
\text { Period }\end{array}$ & Rijswijk & Abingdon & $\begin{array}{c}\text { Milford } \\
\text { Haven }\end{array}$ \\
\hline \multicolumn{1}{c}{1959} & & & \\
January & 45 & 77 & 47 \\
February & 43 & 51 & 47 \\
March & 48 & 29 & 43 \\
April & 15 & 27 & 17 \\
May & 17 & 21 & 26 \\
June & 21 & 23 & 42 \\
July & 24 & 40 & 47 \\
August & 45 & 63 & 62 \\
September & $27^{*}$ & 92 & 92 \\
October & 51 & 101 & 87 \\
November & 102 & 102 & 73 \\
\hline
\end{tabular}

* Activities were low this month, due to low rainfall. Therefore the error may be relatively large.

equatorial $\mathrm{Sr}^{90}$ rose rapidly and approached values near 100 per cent.

In an attempt to calculate the relative amounts of air from the polar and temperate stratosphere that brought $\mathrm{Sr}^{90}$ into the troposphere during the spring of 1959, Machta [1960] assumed that 60 per cent of tropospheric debris originated from the Soviet October 1958 explosions. This is somewhat lower than the result of the calculation mentioned above.

It is somewhat surprising that during the summer of 1959 the $\mathrm{W}^{185} / \mathrm{Sr}^{90}$ ratios were not significantly lower than the ratios found at the end of 1959 and in 1960, whereas the contribution from arctic tests diminished gradually to pr tically zero during the second half of 1959 . minimum in the $\mathrm{W}^{186} / \mathrm{Sr}^{90}$ ratio would have been expected at the time of the maximum percentage of fallout from the Soviet October 1958 tests. Such a minimum was indeed found in the northern hemisphere by Lockhart, Patterson, Saunders, and Black [1960b] and also, although less pronounced, by Walton [1960].

The $\mathrm{W}^{185} / \mathrm{Sr}^{90}$ ratio in equatorial debris might not have been constant in 1959. In this connection it is important to note that in NovemberDecember 1959 the $W^{185}$ maximum over the equator resided at about $70,000 \mathrm{ft}$ whereas the maximum $\mathrm{W}^{185} / \mathrm{Sr}^{90}$ ratio was found at 60,000 $\mathrm{ft}$ [Feely and Spar, 1960]. This may be due to the different altitudes reached by the clouds of 
equatorial test explosions, resulting in a nonhomogeneous distribution of $\mathrm{W}^{185}$ and $\mathrm{Sr}^{90}$.

Nonhomogeneity of the equatorial debris with respect to $\mathrm{W}^{185}$ and $\mathrm{Sr}^{90}$ is suggested also by $\mathrm{W}^{186} / \mathrm{Sr}^{90}$ and $\mathrm{Sr}^{89} / \mathrm{Sr}^{90}$ ratios found in the troposphere [Lockhart and others, 1960b]. Whereas the $\mathrm{Sr}^{89} / \mathrm{Sr}^{90}$ ratio in ground-level air in the southern hemisphere, corrected for decay, increased by a factor of about 4 during 1959 , the average $W^{185} / \mathrm{Sr}^{90}$ ratio remained approximately constant, showing a slight maximum in May.

The possibility of varying $\mathrm{W}^{185} / \mathrm{Sr}^{90}$ ratios in debris from the equatorial explosions during 1959 precludes a reliable assessment of the fraction of equatorial $\mathrm{Sr}^{90}$ in fallout based on $\mathrm{W}^{185}$ data. Therefore, the $\mathrm{Sr}^{89} / \mathrm{Sr}^{90}$ ratio in the stratosphere was used as a basis for the calculation of the values in Table 2.

Conclusion. There is evidence that no debris from the Soviet detonations in October 1958 was present in the lower stratosphere at the end of 1959 and that during 1960 fallout consisted mainly of material from explosions in tropical areas. This material was characterized by a $\mathrm{W}^{185} / \mathrm{Sr}^{90}$ ratio of 40 to 80 on June 15,1958 , and a $\mathrm{Ce}^{144} / \mathrm{Sr}^{90}$ ratio of about 22 on November 1 , 1958 (Figs. 1, 2, and Table 1). The contribution of equatorial explosions to fallout in 1959 is strongly underestimated when it is calculated from $W^{185}$ data using a $W^{185} / \mathrm{Sr}^{90}$ ratio of 380 on June 15, 1958 [Martell and Drevinsky, 1960], or 500 on July 15, 1958 [Lockhart and others, 1960a]. Nevertheless, during the spring maximum of 1959 the contribution of Soviet debris from the October 1958 explosions amounted to 70 to 85 per cent (Table 2) in western Europe.

Acknowledgment. We are indebted to Dr. M. Wijnans for analyzing the $\mathrm{Ce}^{144} / \mathrm{Sr}^{90}$ duplicates statistically and to Mr. M. H. J. Huguenin for help with the $\gamma$-ray spectrometer.

\section{REFERENCES}

Bleichrodt, J. F., Joh. Blok, and R. H. Dekker, On the spring maximum of radioactive fallout from nuclear test explosions, J. Geophys. Research, 66 , 135-141, 1961.

Crooks, R. N., R. G. D. Osmond, E. M. R. Fisher, M. J. Owers, and T. W. Evett, The deposition of fission products from distant nuclear test explossions. Results to the middle of $1960, A E R E-R$
3349, United Kingdom Atomic Energy Authority, Harwell, 1960.

Crooks, R. N., R. G. D. Osmond, M. J. Owers, and E. M. R. Fisher, The deposition of fission products from distant nuclear test explosions. Results to mid-1959, AERE-R 3094, United Kingdom Atomic Energy Authority, Harwell, 1959.

Feely, H. W., and J. Spar, Tungsten-185 from nuclear bomb tests as a tracer for stratospheric meteorology, Nature, 188, 1062-1064, 1960.

Glendenin, L. E., K. F. Flynn, R. F. Buchanan, and E. P. Steinberg, Radiochemical determination of cerium in fission, Anal. Chem., 27, 59$60,1955$.

Kreger, W. E., and R. L. Lynn, A measurement of the decay of ${ }^{181} \mathrm{~W}$, Nuovo cimento, $18,829-836$, 1960.

Lockhart, L. B., R. A. Baus, R. L. Patterson, and A. W. Saunders, Radiochemical analyses of airfilter samples collected during 1958, NRL Rept. 5390, U. S. Naval Research Laboratory, Washington, D. C., 1959.

Lockhart, L. B., R. L. Patterson, A. W. Saunders, and R. W. Black, Contribution of Hardtack debris to contamination of the air during 1959 , Science, 132, 154, 1960a.

Lockhart, L. B., R. L. Patterson, A. W. Słunders, and $\mathrm{R}$. W. Black, Fission product radioactivity in the air along the 80th meridian (West) during 1959, J. Geophys. Research, 65, 3987-3997, $1960 b$.

Machta, L., An attempt to compute relative removal rates from the polar and temperate latitude stratosphere in the spring 1959, in Fallout Program Quarterly Summary Report, HASL-95, Health and Safety Laboratory, U. S. Atomic Energy Commission, New York, October 1, 1960.

Martell, E. A., and P. J. Drevinsky, Atmospheric transport of artificial radioactivity, Science, 132, 1523-1531, 1960.

Osmond, R. G., M. J. Owers, C. Healy, and A. P. Mead, The determination of radioactivity due to caesium, strontium, barium and cerium in waters and filters, $A E R E-R$ 2899, United Kingdom Atomic Energy Authority, Harwell, 1959.

Stebbins, A. K., editor, A special report on the high altitude sampling program, Defence Atomic Support Agency, DASA 532, Washington, D. C., 1960.

Strominger, D., J. M. Hollander, and G. T. Seaborg, Table of isotopes, Revs. Modern Phys., 30, 585-904, 1958.

Walton, A., Tungsten-185 in precipitation and the seasonal variations in fall-out, Nature, 188, 220221, 1960.

Welford, G. A., W. R. Collins, D. Sutton, and R. Morse, The sequential analysis of ten nuclides occurring in long range fallout debris, $H A S L-57$, Health and Safety Laboratory, U. S. Atomic Energy Commission, New York, 1959.

(Manuscript received March 13, 1961; revised May 5, 1961.) 
